\title{
Kasugamycin on Leifsonia xyli subsp. xyli in the in vitro culture of sugarcane
}

\author{
Fabio Ribeiro Garcia ${ }^{1^{*}}$ (D) Felipe Lira de Sá Cavalcante ${ }^{1}$ (D) \\ Robson Antonio de Souza $^{1}$ Laureen Michelle Houllou' ${ }^{1}$ iD
}

${ }^{1}$ Centro de Tecnologias Estratégicas do Nordeste, Laboratório de Pesquisas Aplicadas à Biofábricas, Cidade Universitária, 50740-545, Recife, PE, Brasil. E-mail: fabiogarcia.5@gmail.com. .Corresponding author.

\begin{abstract}
One of the significant obstacles to the growth of sugarcane production is the infection by phytopathogens, mainly by the bacterium Leifsonia xyli subsp. xyli (Lxx) causal agent of Ratoon stunting disease. Thus, this research aimed to evaluate the effects of kasugamycin on the in vitro growth of sugarcane, as well as its effect on the bacterium Lxx. Explants of strain SP791011 from sugarcane were inoculated in MS culture medium supplemented with the antimicrobial kasugamycin at concentrations of $0.00 ; 0.87 ; 1.08 ; 1.74$ and $3.48 \mathrm{~mL} . \mathrm{L}^{-1}$, where they remained for 30 days. After this period, the survival rate, shoot number per explant, height of the explants, phytomass, dry phytomass and phytosanitary were evaluated based on the presence of genomic DNA of Lxx. It was verified that the culture in kasugamycin influenced the morphological variables negatively; nevertheless, the antimicrobial did not demonstrate phytotoxicity to the plants. All treatments tested in this experiment were diagnosed as positive, with DNA amplification for Lxx, despite it was observed a reduction in bacterial load, suggesting that kasugamycin at higher doses can be evaluated as an attempt to eliminate the bacterium in the in vitro cultivation of sugarcane.

Key words: micropropagation, endophytic, Ratoon stunting disease.
\end{abstract}

Efeitos da Kasugamicina em Leifsonia xyli subsp. xyli na cultura in vitro de cana-de-açúcar

RESUMO: Um dos maiores entraves para o crescimento da produção de cana-de-açúcar é a infecção por fitopatógenos, principalmente pela bactéria Leifsonia xyli subsp. xyli (Lxx), agente causal do raquitismo-da-soqueira, doença que mais causa perdas a cultura. Assim, este trabalho teve como objetivo, avaliar os efeitos do antimicrobiano casugamicina sobre o crescimento in vitro, bem como seu efeito sobre a infeç̧ão endógena por Lxx em cana-de-açúcar. Explantes da variedade SP791011 de cana-de-açúcar foram inoculados em meio de cultura MS suplementados com o antimicrobiano nas concentrações de 0,00; 0,87; 1,08; 1,74 e 3,48 mL. $L^{-1}$, em que permaneceram por 30 dias. Após este período, foi avaliada a taxa de sobrevivência, número de brotações por explante, altura dos explantes, fitomassa, fitomassa seca e fitossanidade em relação à presença de DNA genômico de Lxx. Foi verificado que o cultivo em casugamicina influenciou de forma negativa nas variáveis morfológicas, apesar disso, o antimicrobiano não mostrou fitotoxidade às plantas. Todos os tratamentos testados neste experimento foram diagnosticados como positivos, com amplificação de DNA para Lxx, apesar de ter sido observada uma redução na carga bacteriana, sugerindo que a casugamicina em doses superiores pode ser avaliada como alternativa na tentativa de eliminar completamente a bactéria no cultivo in vitro de cana-de-açúcar.

Palavras-chave: micropropagação, endofiticos, raquitismo-da-soqueira.

Brazil ranks as number one among the world's largest sugar cane producers (Saccharum ssp), with 647.6 million tons in the $2017 / 2018$ harvest and a planted area of 8.838 .5 thousand hectares, representing $22 \%$ of all world production (CONAB, 2018).

The economic relevance of sugarcane production has been mainly associated with the production of sugar and ethanol (MORAIS et al., 2018) and raw material for the production of second generation ethanol (AZEVEDO et al., 2011). One of the significant problems in the cultivation of sugarcane is the contamination by systemic phytopathogens, among them, Leifsonia xyli subsp. $x y l i(\mathrm{Lxx})$, the causal agent of ratoon stunting disease (RSD), one of the most important diseases in this culture. The RSD is characterized by the reduction of stem diameter and shortening of internodes, leading to a decrease of sugarcane productivity (CARVALHO et al., 2016), causing significant losses of up to $60 \%$ of its biomass (LI et al . 2013). The thermally treated stems is the most widely used method for the control of RSD. However, the thermal treatment presents low efficiency, not eliminating the bacteria present inside the treated stems (URASHIMA et al., 2012). Biotechnological techniques such as plant 
tissue culture have been used for clonal cleaning (SILVA et al., 2013), and when associated with other technologies, such as thermotherapy, chemotherapy or both, can significantly favor the chances of success of the method (PANATTONI et al., 2007).

The objective of this research was to evaluate the antimicrobial action of kasugamycin on the endogenous infection by Leifsonia xyli subsp. $x y l i$, a bacterium that causes RSD and to investigate the phytotoxic effect of the drug on sugarcane cultivated in vitro.

For in vitro culture, MS culture medium (MURASHIGE \& SKOOG, 1962) was used with $100 \mathrm{mg} . \mathrm{L}^{-1}$ myo-inositol, $0.1 \mathrm{mg} . \mathrm{L}^{-1}$ BAP (benzylaminopurine), $0.1 \mathrm{mg} \mathrm{L}^{-1} \mathrm{Kin}$ (Kinetin) and $30 \mathrm{~g} \mathrm{~L}^{-1}$ sucrose, then the $\mathrm{pH}$ of the medium was adjusted to 5.8. The culture medium was autoclaved in $500 \mathrm{ml}$ Erlenmeyer flasks where $300 \mathrm{ml}$ of culture medium was transferred to each Erlenmeyer and after sealing with aluminum foil and PVC film were autoclaved for 20 minutes at $121{ }^{\circ} \mathrm{C}$ and pressure of $1 \mathrm{kgf} . \mathrm{cm}^{-2}$. After autoclaving, the Erlenmeyer flasks were transferred to a laminar flow chamber, and when the culture medium reached a temperature of $25{ }^{\circ} \mathrm{C}$, measured using a digital thermometer, the antimicrobial kasugamycin was added at concentrations of $0.87 ; 1.08 ; 1.74$ and 3.48 mL.L ${ }^{-1}$, plus 1 (one) control treatment, without the addition of kasugamycin, totaling 5 (five) treatments.

For the addition of kasugamycin to the culture medium, the antimicrobial was filtered in a 0.22 $\mu \mathrm{m}$ Millipore filter and distributed in the Erlenmeyer flasks with the aid of a $1000 \mu \mathrm{l}$ micropipette with a sterile barrier tip. After the addition of kasugamycin, the Erlenmeyer was shaken manually until complete homogenization of the culture medium. Then, with the aid of a $50 \mathrm{~mL}$ graduated beaker, $30 \mathrm{~mL}$ of culture medium was dispensed into glass vials with a total volume of $200 \mathrm{~mL}$.

As the source of explants, sugarcane plants of the SP791011 variety, already established in vitro, were used from the research collection of the Centro de Tecnologias Estratégicas do Nordeste (CETENE), located in Recife, PE. In a laminar flow chamber, clumps of sugarcane cultivated in vitro were selected, which were reduced to groups with 3 (three) shoots, so that each sprout was approximately 3 centimeters high and 0.5 centimeters in diameter, then transferred to vials containing culture medium with kasugamycin.

After explants transfer, the cultures were maintained in a growth room with a temperature of $25 \pm 2{ }^{\circ} \mathrm{C}$, with a photon flux density of $50 \mathrm{~mol}$ $\mathrm{m}^{-2} \cdot \mathrm{s}^{-1}$ and photoperiod of $16 \mathrm{~h}$ where they remained for 30 days. At the end of this period, percentage of survival (\%), number of shoots per explant, the height of explants $(\mathrm{cm})$, phytomass $(\mathrm{g})$, dry phytomass ( $\mathrm{g}$ ) and phytosanitary were evaluated to the presence of Lxx.

For each treatment with the antimicrobial, ten replicates were used, each replicate comprising 1 (one) vial containing 3 (three) explants, where each explant consisted of 3 (three) shoots each. The observed data were transformed into $\sqrt{ } x+0.5$, aiming to satisfy the assumptions of the analysis of variance, and submitted to the Tukey test, with the aid of the statistical program Sisvar (FERREIRA, 2014).

For the molecular diagnosis, leaf fragments were used. In laminar flow chamber with the aid of sterile scalpel, leaves were cut and weighed, up to $100 \mathrm{mg}$ per microtube, then the samples were frozen with liquid nitrogen and macerated via Tissue Lyser $\left(\right.$ Qiagen $\left.^{\circledR}\right)$. The samples were submitted to DNA extraction using the Wizard ${ }^{\circledR}$ Genomic DNA Purification Kit (Promega) and quantified by spectrophotometry in Nanodrop ${ }^{\circledR}$.

For pathogen identification, the primers LxxW.1 (5 'CAGAGCACCATCGTGAAGAC 3') and LxxW.2 (5 'AAGGACAAGTCCACCAAGGA 3'), specific for Lxx, were used. The cycling conditions were: initial denaturation at $94{ }^{\circ} \mathrm{C}$ for 5 minutes, followed by 35 cycles of denaturation at $94{ }^{\circ} \mathrm{C}$ for 45 seconds, annealing at $56^{\circ} \mathrm{C}$ for 30 seconds, extension at $72{ }^{\circ} \mathrm{C}$ for 60 seconds, followed by a final extension at $72{ }^{\circ} \mathrm{C}$ for 10 minutes (DANTAS et al., 2017).

After each PCR reaction, the amplicons were submitted to $2 \%$ agarose gel electrophoresis and visualized with the aid of a transilluminator with ultraviolet light. The generated amplicons were visualized as bands, and samples containing 182 $\mathrm{bp}$ fragment were considered positive, using as a comparison a marker of molecular weight of $100 \mathrm{bp}$.

Among the evaluated treatments, it was verified that the addition of kasugamycin to the culture medium did not present a phytotoxic effect since it did not affect the survival and the development sugarcane explants. Even in the highest concentration of kasugamycin, $3.48 \mathrm{~mL} . \mathrm{L}^{-1}$, the survival of $86.6 \%$ of explants was observed, which did not differ statistically from the other treatments, with lower concentrations (Table 1).

Probably, because it is a systemic antimicrobial and fungicide, able of being translocated through the plant vascular system, kasugamycin has not demonstrated a phytotoxic effect on sugarcane explants. This behavior is described by several 
Table 1 - Percent of explant survival, shoot number per explant, shoot height, phytomass and dry matter of explants of sugarcane, variety SP 791011, as a function of different concentrations of kasugamycin.

\begin{tabular}{|c|c|c|c|c|c|}
\hline Casugamicina $\left(\mathrm{mL} \cdot \mathrm{L}^{-1}\right)$ & Survival (\%) & $\mathrm{N}^{\circ}$ Shoots/explant & Shoot height $(\mathrm{cm})$ & Fresh phytomass (g) & Dry phytomass (g) \\
\hline 0.00 & $100.0 \mathrm{a}$ & $10.80 \mathrm{a}$ & $10.17 \mathrm{a}$ & $5.08 \mathrm{a}$ & $0.36 \mathrm{a}$ \\
\hline 0.87 & $100.0 \mathrm{a}$ & $12.60 \mathrm{a}$ & $10.26 \mathrm{a}$ & $5.10 \mathrm{a}$ & $0.41 \mathrm{a}$ \\
\hline 1.08 & $100.0 \mathrm{a}$ & $13.60 \mathrm{a}$ & $9.93 b$ & $4.62 \mathrm{a}$ & $0.39 \mathrm{a}$ \\
\hline 1.74 & $90.0 \mathrm{a}$ & $10.50 \mathrm{a}$ & $7.27 \mathrm{~b}$ & $3.69 \mathrm{~b}$ & $0.22 b$ \\
\hline 3.48 & $86.6 \mathrm{a}$ & $7.70 \mathrm{~b}$ & $7.06 \mathrm{~b}$ & $2.27 \mathrm{~b}$ & $0.19 b$ \\
\hline CV (\%) & 7.06 & 20.51 & 18.17 & 28.83 & 32.36 \\
\hline Average value & 95.33 & 11.04 & 8.93 & 4.15 & 0.31 \\
\hline
\end{tabular}

Vallues followed by equal letters in the columns, do not differ statistically from each other, by the Tukey test (P $\leq 0.05)$.

authors, who mentioned that antimicrobials such as ampicillin, carbenicillin, cephalosporins, and rifampicin have low phytotoxicity in vitro culture (FISSE et al., 1987; SANTOS \& SALEMA, 1989). According to KONEMAMM et al. (2001), the absence of phytotoxicity is probably because some antimicrobials have action on specific sites of microorganisms, not acting on plant cells. Kasugamycin is a small molecule of aminoglycoside that binds to the bacterial $30 \mathrm{~S}$ ribosomal subunit, thereby inhibiting the initiation of mRNA translation into bacterial proteins (WILSON, 2014), and is therefore, innocuous for sugarcane explants.

For all morphological variables analyzed, a significant difference was observed (Table 1). For the number of shoots formed per explant, only treatment 5 (five), with $3.48 \mathrm{~mL} \mathrm{~L}^{-1}$ of kasugamycin showed a decrease in the multiplication rate, all other treatments being statistically the same. For the height of the aerial part, phytomass and dry phytomass, a decrease was observed from the treatment with 1.74 mL. $\mathrm{L}^{-1}$ of kasugamycin, evidencing the negative influence of this antimicrobial on these variables. Results of the molecular diagnosis of Lxx showed that there was a reduction of the bacterial load as the antimicrobial concentration increased (Figure 1), suggesting apparent effectiveness of kasugamycin in reducing the bacterial amount of Lxx in the vascular system of sugarcane.

Use of antimicrobials on in vitro culture is an effective practice for the control of endogenous bacterial contaminations; however, it is difficult to

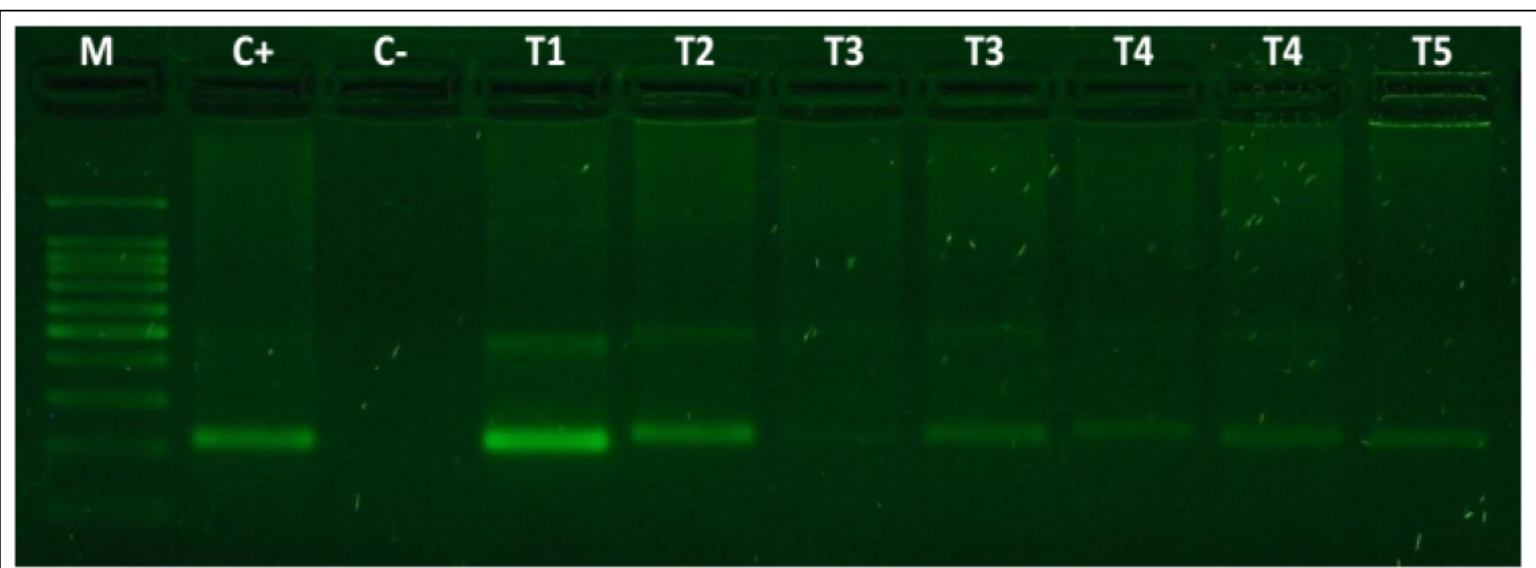

Figure 1 - PCR electrophoresis gel photo for Lxx of leaf material from explants submitted to in vitro culture with kasugamycin. Where: M $=$ molecular weight marker; $\mathrm{C}+=$ positive control; $\mathrm{C}-=$ negative control; $\mathrm{T} 1=0.00 ; \mathrm{T} 2=0.87 ; \mathrm{T} 3=1.08 ; \mathrm{T} 4=1.74$ and $\mathrm{T} 5=3.48$ mL.L-1 of kasugamycin. 
eliminate microorganisms, since the drugs commonly used in plant tissue culture have bacteriostatic and non-bactericidal action (DONATO et al., 2005). It is possible that the doses of kasugamycin used in this study were insufficient to observe the expected bactericidal effect of the antimicrobial on Lxx.

All samples submitted to the treatments evaluated in this study were diagnosed as positive for Lxx (presence of amplified bacterial DNA); although, a bacteriostatic effect was observed with a reduction in bacterial load. Also, none of the concentrations of kasugamycin had a phytotoxic effect on the explants, suggesting that higher levels of this antimicrobial can be tested to eliminate Lxx of SP791011 during in vitro culture.

\section{ACKNOWLEDGEMENTS}

The authors thank the Conselho Nacional de Desenvolvimento Científico e Tecnológico (CNPq), the Coordenação de Aperfeiçoamento de Pessoal de Nível Superior (CAPES) and the Fundação de Amparo à Pesquisa do Estado de Pernambuco (FACEPE) for their support.

\section{DECLARATION OF CONFLICT OF INTERESTS}

The authors declare no conflict of interest. The founding sponsors had no role in the design of the study; in the collection, analyses, or interpretation of data; in the writing of the manuscript, and in the decision to publish the results.

\section{AUTHORS' CONTRIBUTIONS}

All authors contributed equally for the conception and writing of the manuscript. All authors critically revised the manuscript and approved of the final version.

\section{REFERENCES}

AZEVEDO, R.A. et al. Sugarcane under pressure: an overview of biochemical and physiological studies of abiotic stress. Tropical Plant Biology, v.4, p.42-51, 2011. Available from: <http://link.springer.com/article/10.1007\%2 Fs12042-011-9067-4>. Accessed: May, 15, 2018. doi:10.1007/ s12042-011-9067-4.

CONAB-Companhia Nacional de Abastecimento. Acompanhamento da safra brasileira de cana-de-açúcar. - v. 1 Brasília : Conab, 2018- v.4. $n^{\circ} 1$ ISSN 2318-7921, v. 4 - Safra 2017/18, n. 1

DANTAS, P.V.P et al. Nanoparticle-assisted Polymerase Chain Reaction (NanoPCR): Optimization of PCR detection of Leifsonia xyli subsp. xyli by the addition of nanoparticles. Journal of Applied and Advanced Research, v.2, p.13-20, 2017. Available from: <https://phoenixpub.org/journals/ index.php/jaar/article/view/47>. Accessed: Apr. 30, 2019. doi: 10.21839/jaar.2017.v2i1.47.
DONATO, V.M.T.S. et al. Sugar cane plants cultivated in vitro with antibiotics. Ciência e Agrotecnologia, Lavras, v.29, n.1, p.134- 141. 2005. Available from: <http://www.scielo.br/scielo. php? script $=$ sci arttext $\&$ pid $=$ S1413-70542005000100017>. Accessed: May, 25, 2018. doi: 10.1590/S141370542005000100017.

FERREIRA, D. F. Sisvar: a guide for its bootstrap procedures in multiple comparisons. Ciência eAgrotecnologia, Lavras, v.38, n.2, p.109-112, 2014. Available from: <http://www.scielo.br/scielo. php? script $=$ sci arttext\&pid $=$ S1413-70542014000200001 $>$. Accessed: May, 15, 2018. doi: 10.1590/S141370542014000200001 .

FISSE, J. Endogenous bactéria elimination in ornamental plants. Acta Horticulturae, Wageningen, v.212, p.8790, 1987. Available from: <https://www.actahort.org/ books/212/212 11.htm>. Accessed: Jun. 21, 2018. doi: 10.17660/ActaHortic.1987.212.11.

CARVALHO, G. et al. Development of a qPCR for Leifsonia $x y l i$ subsp. xyli and quantification of the effects of heat treatment of sugarcane cuttings on Lxx. Crop Protection, v.80, p.51-55, 2016. Available from: <https://www.sciencedirect.com/science/ article/pii/S0261219415301551>. Accessed: May, 15, 2018. doi: 10.1016/j.cropro.2015.10.029.

KONEMAN, E.W. et al. Provas de sensibilidade a agentes antimicrobianos. In: Diagnóstico microbiológico. São Paulo: Medsi. p.795-865. 2001

LI. W. et al. PCR detection of ratoon stunting disease pathogen and natural resistance analysis in sugarcane core germplasms. Crop Protection, v.53, p.46-51. 2013. Available from: $<$ https://www.sciencedirect.com/science/article/pii/ S026121941300166X>. Accessed: May, 25, 2018. doi: 10.1016/j.cropro.2013.06.011.

MORAIS, M. B. et al. Multiple stresses on the oxidative metabolism of sugarcane varieties. Ciência Rural. v.48, 2018. Available from: <http://www.scielo.br/scielo.php?script=sci ar ttext\&pid $=$ S0103-84782018000400201>. Accessed: May, $\overline{25}$, 2018. doi: $10.1590 / 0103-8478 \mathrm{cr} 20141487$.

MURASHIGE, T.; SKOOG, F.A. A revised medium for rapid growth and bioassays with tobacco tissue culture. Physiology Plantarum, v.15, p.473-497, 1962. Available from: <https:// onlinelibrary.wiley.com/doi/10.1111/j.1399-3054.1962. tb08052.x>. Accessed: Jul. 25, 2018. doi: 10.1111/j.13993054.1962.tb08052.x

PANATTONI, A. et al. Grapevine vitivirus A eradication in Vitis vinifera explants by antiviral drugs and thermotherapy. Journal of Virological Methods, v.146, n.1, p.129-135, 2007. Available from: <https://www.sciencedirect.com/science/ article/pii/S0166093407002273>. Accessed: Apr. 5, 2019. doi: 10.1016/j.jviromet.2007.06.008

SANTOS, I; SALEMA, R. Penicillins and activity of nitrogen metabolism enzymes in plant tissue culture. Plant Science, v.59, p.119-125, 1989. Available from: <https://www.sciencedirect. com/science/article/pii/0168945289900162>. Accessed: Jun. 25, 2018. doi: 10.1016/0168-9452(89)90016-2.

SILVA, A. M. F. et al. Clonal cleaning of grapevine plants infected by Xanthomonas campestris pv. viticola. Revista 
Brasileira de Fruticultura, v.35, n.1, p.316-319. 2013. Available from: <http://www.scielo.br/pdf/rbf/v35n1/36. pdf>. Accessed: Jun. 21, 2018. doi: 10.1590/S010029452013000100036.

URASHIMA, A. S.; GRACHET, N. G. Detection method for Leifsonia xyli subsp. xyli and effect of thermotherapy on bud germination in sugarcane varieties. Tropical Plant Pathology, v.37, n.1, p.57-64, 2012. Available from:
$<$ http://www.scielo.br/scielo.php?script=sci_arttext\&pid $=$ S1982-56762012000100007>. Accessed: Aug. 21, 2018. doi: $10.1590 / \mathrm{S} 1982-56762012000100007$

WILSON, D. N. Ribosome-targeting antibiotics and mechanisms of bacterial resistance. Nature Reviews Microbiology, 12, 35-48. 2014. Available from: <https://www.nature.com/ articles/nrmicro3155>. Accessed: Aug. 20, 2018. doi: 10.1038/ nrmicro3155. 